\title{
A NEW METHOD OF TESTING BEANS FOR ANTHRACNOSE
}

\author{
A. C. v. d. GIESSEN and A. v. STEENBERGEN \\ Institute of Horticultural Plant Breeding, Wageningen, Holland \\ Received 19 Febr. 1957
}

Resistance to anthracnose (Colletotrichum lindemuthianum) is an important item of every bean breeding programme. The testing of beans for disease-resistance can be carried out more efficaciously by the application of artificial infection. The chances of escape will thus be greatly reduced and if seedlings can be inoculated at a very young stage it moreover becomes possible to minimize expenses and the amount of labour involved.

Infecting beans with anthracnose can be performed by the method of LABRUYÈRE and Hubbeling. After removal of the seedcoat the germinated seeds, placed on filter paper, are inserted in wide culture tubes which contain some water. They are kept in the tubes for a couple of days to enable the young seedlings to develop a little. Next these seedlings are sprayed with a spore suspension. High humidity is obtained by closing the tubes with a moist plug of wadding. The tubes are then placed in a room at a temperature of $15-22^{\circ} \mathrm{C}$. Two days after inoculation the plants are potted up to be selected later. It is also possible to keep them in the tubes until the susceptible plants are dead.

If the number of plants to be tested is small, this method gives very good results; if many plants have to be tested, however, it is rather laborious and costly. Therefore a simpler and cheaper method was developed at our Institute; it has already been applied with success. In principle both methods are alike, but it has now become possible to make use of material that in many cases is already available at the breeding establishments.

\section{MATERIALS USED}

Zinc containers about $10 \mathrm{~cm}$ high or wooden boxes covered on the inside with plastic.

Perforated zinc sheets (perforations 1.5 or $2 \mathrm{~cm}$ in diameter) provided with an upturned edge a few $\mathrm{cm}$ high, or frames made from laths which are covered with fine wire-netting. These sheets and frames should fit into the containers.

Plastic film (polythene) and filter paper.

\section{Procedure}

\section{Germination of seed}

For this purpose use can be made of a Dutch light. This is covered with plastic which in its turn is cased over with a double layer of moist filter paper. After the seeds have been disinfected to prevent the formation of fungi, e.g. with a TMTD containing disinfectant, they are placed on the filter paper and covered with another layer of moist 


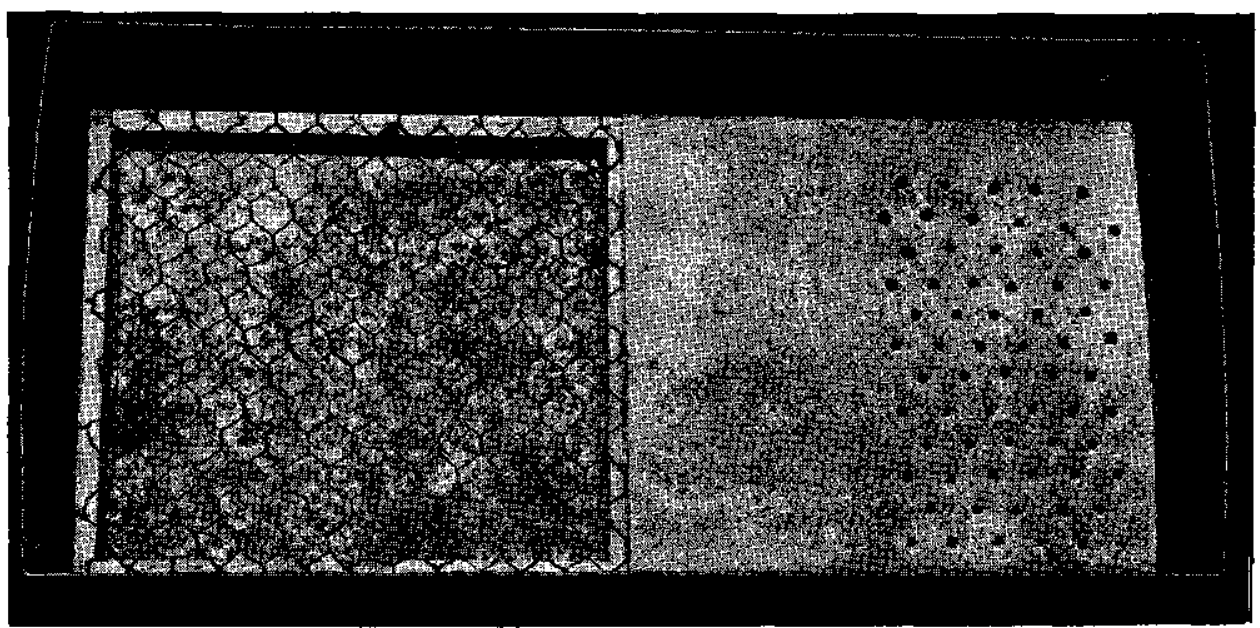

Fig. 1. Zinc CONTAiner WITH FRAME, PARTLy COVERED WITH FILTER PAPER

filter paper. It is desirable to cover the whole with plastic to prevent drying out. Germination can take place at room temperature.

\section{Inserting the frames in the containers}

As soon as the seeds have germinated to such an extent that the roots are 2 or $3 \mathrm{~cm}$ long the seed-coat is removed. This provides a better exposure of the young seedlings to the spore suspension. The seed-coat can be best removed after soaking the seeds in water.

A sheet of filter paper is folded round the frames and then perforated by means of a lead-pencil (Fig. 1). The young seedlings are then placed on the filter paper with their roots through the holes. Next the frames are inserted in the containers, which are filled with water to a depth of about $1 \mathrm{~cm}$. To enable the paper to absorb moisture it should be immersed in the water (Fig. 2). The seedlings are left in the container for a couple of days until they have developed to some extent.

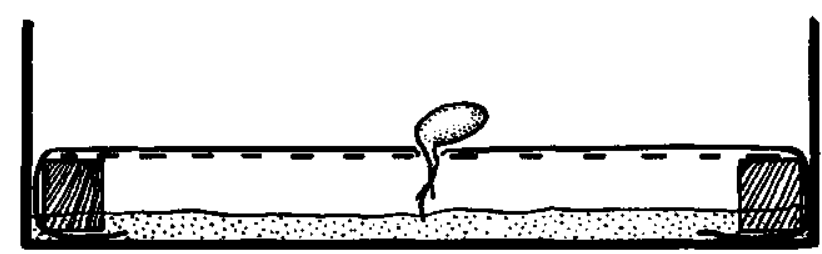

Fig. 2. Cross Section of a CONTAiner

\section{Infection}

As soon as the young seedlings have sufficiently developed they are sprayed with a spore suspension by means of a hand sprayer or a rubber-bulb syringe. Special care should be taken that all plants are sprayed properly. In order to have sufficient infection material at hand it is of importance to maintain the different phsyiological races of 


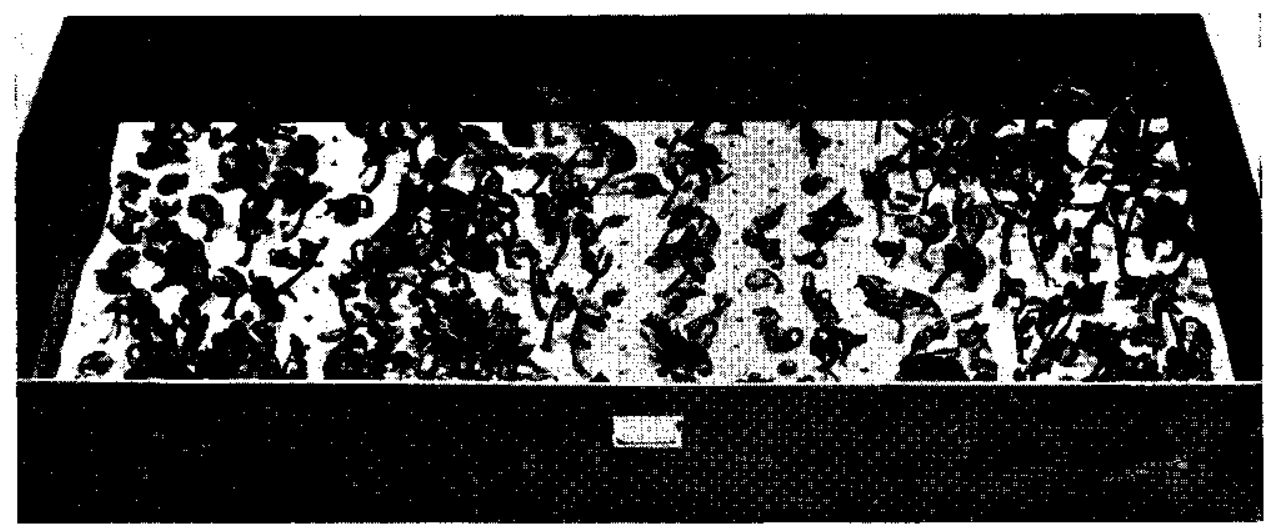

FIG. 3. FIRST SYMPTOMS OF THE DISEASE ON SUSCEPTIBLE PLANTS

the fungus on an artificial substratum. For this purpose use is made of pepton agar on which the fungus produces spores profusely. The suspensions of the different biological strains can be sprayed separately or mixed.

A temperature of $15-22^{\circ} \mathrm{C}$ and high air humidity are required for the development of the fungus. High humidity is obtained by closing the containers carefully with plastic film. Wooden containers should previously have been sufficiently moistened. The containers are then placed in a room where it is possible to maintain the optimum temperature, for instance in a cellar or a room with a northern aspect. The young plants should receive sufficient light, otherwise they will stretch markedly.

\section{Selection}

After 3 days the plastic is detached and removed the following day. It is essential, however, to maintain a humid atmosphere by applying a mist to the plants at intervals.

The plants can be selected 7-10 days after inoculation. The stems and leaves of the susceptible plants are often so strongly affected that the plants fall over (Fig. 3). A single brown spot is no objection, although one should aim at selecting plants that are entirely healthy.

\section{SUMMARY}

1. In breeding beans it is possible to test the seedlings for resistance to anthracnose already at a very early stage.

2. So far these tests have been carried out by the method of LABRUYÈre and HuBBELING in which culture tubes are used.

3. A new method, based on the same principles but simpler and less costly, has been developed at the Institute of Horticultural Plant Breeding. According to this method the young seedlings are placed on frames which are inserted in zinc or wooden containers. Then they are infected. The temperature is kept at $15-22^{\circ} \mathrm{C}$ and high air humidity is obtained by covering the containers with plastic. 


\section{A NEW METHOD OF TESTING BEANS}

\section{SAMENVATTING}

Een nieuwe methode voor de toetsing van bonen op resistentie tegen vlekkenziekte

1. Bij de veredeling van bonen kan reeds in het kiemplantstadium worden getoetst op resistentie tegen vlekkenziekte.

2. Tot dusver werd deze toetsing uitgevoerd met behulp van grote cultuurbuizen.

3. Door het I.V.T. werd een methode uitgewerkt, die in principe gelijk, doch eenvoudiger en minder kostbaar is. De kiemplanten worden op raampjes in zinken of houten bakken geplaatst en daarna besmet. De temperatuur blijft gehandhaafd op $15-22^{\circ} \mathrm{C}$, terwijl voor het verkrijgen van een hoge luchtvochtigheid deze bakken worden afgesloten met plastic.

\section{LITERATURE CITED}

HubBeling, N., Jaarverslag 1955, Instituut voor Plantenziektenkundig Onderzoek, Wageningen, pp. 146-148. 